\title{
PENGARUH KUALITAS PELAYANAN TERHADAP KEPUASAN ANGGOTA KOPERASI DOSEN DAN KARYAWAN AUB PANCASILA SURAKARTA
}

\author{
Shandy Marsono ${ }^{1}$ \\ Endah Nawangsasi ${ }^{2}$ \\ STIE Adi Unggul Bhirawa \\ Shandy@stie-aub.ac.id
}

\begin{abstract}
ABSTRAK
Penelitian ini bertujuan untuk mengetahui pengaruh kualitas pelayanan yang meliputi (bukti fisik, reliability, responsivenees, assurance dan empathy) terhadap kepuasan anggota koperasi dosen dan karyawan AUB Pancasila Surakarta Penelitian ini merupakan jenis penelitian survey. Populasi dalam penelitian ini adalah semua anggota koperasi dosen dan karyawan AUB Pancasila Surakarta. Teknik pengambilan sampel yang digunakan non random sampling. Teknik pengambilan yang menyesuaikan diri dengan kriteria tertentu. Penelitian ini menggunakan alat analisis regresi linear berganda, uji t, uji $\mathrm{F}$ dan determinasi. Berdasarkan persamaan regresi linier berganda $Y=Y=6,264+0,283 X_{1}+0,563 X_{2}+0,714 X_{3}-0,567 X_{4}-0,412 X_{5}$ Bahwa nilai konstanta sebesar 6,264 regresi mempunyai konstanta yang mengidentifikasikan bahwa apabila variabel bukti fisik, reliability, responsivenees, assurance, empathy, dianggap konstan atau nol, maka kepuasan anggota koperasi dosen dan karyawan AUB Pancasila Surakarta positif. Hasil perhitungan uji t didapat hasil perhitungan variabel reliability bukti fisik, reliability dan responsivenees, berpengaruh positif signifikam terhadap kepuasan anggota koperasi dosen dan karyawan AUB Pancasila Surakarta. Sedangkan untuk variabel assurance dan empaty berpengaruh tidak signifikan terhadap kepuasan nasabah. Berdasarkan analisis koefisien determinasi $\left(\mathrm{R}^{2}\right)$ diperoleh $\mathrm{R}^{2}$ adjusted sebesar 0,469, memberikan makna bahwa 72,6\% variabel kepuasan anggota dapat dijelaskan oleh variabel bukti fisik, reliability, responsivenees, assurance dan empathy sedangkan sisanya sebesar 27,4\% dijelaskan variabel lain yang tidak dimasukkan dalam model regresi ini misalnya kualitas produk, harga atau biaya dan sebagainya.
\end{abstract}

Kata kunci : bukti fisik, reliability, responsivenees, assurance dan empathy

\section{PENDAHULUAN}

Undang-Undang Republik Indonesia Nomor 17 tahun 2012 Tentang Perkoperasian bahwa pembangunan perekonomian nasonal bertujuan untuk mewujudkan kedaulatan politik dan ekonorni Indonesia melalui pengelolaan sumber daya ekonomi dalam suatu iklim pengembangan dan pemberdayaan koperasi yang memiliki peran strategis dalam tata ekonomi nasional berdasarkan atas kekeluargaan dan demokrasi ekonomi dalam rangka menciptakan masyarakat yang maju, adil, dan makmur berlandaskan Pancasila dan Undang-Undang Dasar Negara Republik Indonesia tahun 1945.

Koperasi agar dapat meningkatkan kualitas pelayanan anggota koperasi harus mampu rnembangun dan meningkatkan kinerja pengurus koperasi dan didukung oleh anggota dan pimpinan lembaga dimana koperasi itu ada. Tujuan koperasi akan tercapai tidak hanya tergantung pada peralatan modern, sarana dan prasarana yang lengkap, tetapi justru lebih tergantung pada kualitas pelayanan yang diberikan pada anggota, Keberhasilan suatu organisasi sungai dipengaruhi oleh kualitas pelayanan diantaranya mutu pelayanan, harga yang bersaing, pelayanan yang maksirnal, terciptanya citra, produk yang baru akan memberikan daya tarik.

Koperasi Dosen dan Karyawan AUB Pancasila Surakarta telah melakukan sebagian dari apa yang diinginkan oleh anggota, bursa telah berupaya untuk menyiapkan kebutuhan, anggota melakukan komunikasi dengan anggota atau daftar barang yang ada dikoperasi, dan apa yang dibutuhkan oleh anggota tetapi belum ada dikonera.si untuk dicatat.

Kepuasan anggota merupakan penentuan yang signifikan dari pengulangan pembelian, informasi dari mulut ke mulut yang positif dan kesetiaan pelanggan. Kepuasan anggota akan mempengaruhi intensitas perilaku untuk membeli jasa dari penyedia jasa yang sama kcpuasan pelanggan dipengaruhi oleh persepsi kualitas ja.sa, kualitas produk, harga dan faktor-faktor yang bersifat pribadi serta yang bersifat situasi sesaat. Salah satu faktor yang menentukan kepuasan anggota adalah persepsi 
pelanggan mengenai kualitas jasa yang berfokus pada lima dimensi kualitas jasa, yaitu, keandalan daya tanggap, jaminan empati dan bukti fisik.

Bukti fisik merupakan seberapa baik penampilan dan kemampuan sarana dan prasarana fisik harus dapat diandalkan. Penampilan fisik pelayanan. karyawan dan komunikasi akan memberikan warna dalam pelayanan anggota. Tingkat kelengkapan peralatan atau teknologi yang digunal.an akan berpengaruh pada pelayanan anggota. Karyawan adalah sosok yang memberikan perhatian terkait dengan sikap, penampilan dan bagaimana menyampaikan kesan pelayanan. Dalam hal ini sejauh mana koperasi memfasilitasi sarana komunikasi sebagai upaya untuk memberikan kemudahan dalam pelayanan adalah hal yang tidak terpisahkan. Keandalan merupakan suatu kemampuan dalam memenuhi janji (tepat waktu, konsisten, kecepatan dalam pelayanan). Pemenuhan janji dalam pelayanan. akan terkait dan mencerminkan kredibilitas koperasi dalam pelayanan. Koperasi berusaha untuk memberikan yang terbaik dalam memenuhi permintaan kebutuhan anggota.

Daya tanggap merupakan suatu kebijakan untuk membantu dan memberikan pelayanan yang cepat kepada anggota. Pada pelayanan. kemampuan untuk segera mengatasi kegagalan secara profesional dapat memberikan persepsi yang positif terhadap kualitas pelayanan.

Jaminan merupakan pengetahuan dan keramahan karyawan serta kemampuan melaksanakan tugas secara spontan yang dapat menjamin kerja yang baik, sehingga menimbulkan kepercayaan dan keyakinan. Tingkat pengetuhuan akan menunjukkan tingkat kepercayaan, sikap ramah, sopan bersahabat adalah menunjukkan adanya perhatian.

Empati adalah memberikan jaminan yang bersifat individual atau pribadi kepada pelanggan dan berupaya untuk memahami keinginan anggota. Tingkat kepedulian dan perhatian koperasi sangat diperlukan oleh anggota. Persoalan dan masalah dapat muncul dan sejauh mana tingkat kepedulian untuk menyelesaikan masalah, mengerti kemauan dan kebutuhan anggota dapat diaktualisasikan. Kepeduiian terhadap masalah yang dihaciapi oleh anggota mendengarkan apa yang dibutuhkan anggota serta berkomunikasi.
Kualitas merupakan inti kelangsungan hidup sebuah lembaga. Gerakan manajemen mutu melalui pendekatan manajemen mutu terpadu menjadi tuntutan yang tidak boleh diabaikan jika lembaga ingin hidup dan berkembang. Para nasabah akan membeli atau menikmati produk jasa suatu perusahaan bila perusahaan memberikan pelayanan yang terbaik dan bermutu kepada mereka. Melihat pentingnya kualitas pelayanan maka peneliti menetapkan judul "PENGARUH KUALITAS PELAYANAN TERHADAP KEPUASAN ANGGOTA KOPERASI DOSEN DAN KARYAWAN / AUB PANCASILA SURAKARTA" (studi kasus pada Koperasi AUB Surakarta).

\section{Landasan Teori}

1. Hubungan kualitas pelayanan terhadap kepuasan nasabah

Menurut Fandy Tjiptono (2004:70 ) dimensi kualitas pelayanan terdiri dari: a) Reability, b) Responsiveness, c) Assurance, d) emphaty dan e) Tangible, yang uraiannya sebagai berikut:

a. Tangible / bukti fisik

Tangible (bukti fisik) adalah kemampuan pihak bank dalam memberikan kenyamanan dan ketersediaan fasilitas fisik. Fasilitas fisik merupakan salah satu aspek yang tidak dapat dipisahkan dari dunia layanan perbankan. Sebab sebaik apapun pelayanan dari karyawan bila tidak ditunjang dengan infrastruktur yang baik, tentu tidak akan memberikan kepuasan yang tinggi kepada nasabah.

b. Reliability

Reliability dapat didefinisikan sebagai kemampuan bank dalam memberikan pelayanan yang tepat, dapat dipercaya dan dapat diandalkan. Atau dengan kata lain seberapa andal pelayanan pihak bank terhadap nasabah. Reliability dapat berhasil karena adanya sumber daya manusia (SDM) yang andal selain itu produk-produk yang diberikan harus sesuai dengan kebutuhan nasabah. Sistem yang sangat majupun menjadi pendukung reliability.

\section{c. Responsiveness}

Responsiveness merupakan kepekaan pihak bank dalam menanggapi setiap keluhan maupun permasalahan yang timbul dari nasabah. Responsiveness juga dapat diartikan kesediaan membantu dan tidak membiarkan 
nasabah menunggu terlalu lama untuk dilayani. Misalnya nasabah perlu menunggu lebih dari lima menit untuk dilayani, karyawan dan satuan pengamanan (satpam) selalu bersedia membantu nasabah, nasabah tidak harus menunggu hingga tiga kali deringan telepon untuk layanan phone banking.

\section{d. Assurance}

Assurance adalah kemampuan bank dalam memberikan pelayanan yang dapat menimbulkan kepercayaan dan rasa aman terhadap nasabah. Kepercayaan dan rasa aman ini harus ditumbuhkan kepada nasabah terutama rasa aman dalam bertransaksi.

\section{e. Emphaty}

$\begin{array}{crr}\text { Emphaty merupakan } & \text { kepedulian } \\ \text { terhadap } & \text { pelayanan }\end{array}$ mementingkan nasabah. Setiap pelanggan tentu ingin diistimewakan atau diberi perhatian khusus pada hal-hal yang disenanginya. Misalnya pemberitahuan informasi terbaru tentang produk dan pelayan, penyediaan waktu pelayanan sesuai dengan kebutuhan pelanggan dan tidak kalah pentingnya, karyawan bank tidak pernah lupa menyebut nama nasabah saat memberikan pelayanan. Dengan kata lain emphaty adalah perhatian khusus yang diberikan pihak bank terhadap nasabah.

Menurut J. Supranto (1997: 56) bahwa untuk mengetahui kinerja pelayanan, konsumen dapat mengukur tingkat kualitas pelayanan yang diberikan dengan menggunakan indikator dibawah ini:

a. Bukti fisik (tangibles) yaitu bukti fisik dari jasa yang menunjang penyampaian pelayanan.

b. Kehandalan (reliability) yaitu kemampuan untuk memberikan pelayanan yang dapat dijanjikan secara tepat dan akumulatif sesuai dengan profesinya. c. Daya tanggap (responsive) yaitu keinginan untuk membantu para konsumen dan memberikan pelayanan sebaik mungkin.

d. Jaminan (assurance) yaitu pengetahuan dan sopan santun para karyawan serta kemampuan menumbuhkan rasa percaya diri para konsumen.

e. Empati (emphaty) yaitu penjiwaan atau perhatian yang terfokus diberikan kepada konsumen.

Dengan indikator-indikator diatas konsumen dapat menilai seberapa besar tingkat kinerja perusahaan. Dan apabila pelayanan yang diberikan dapat memuaskan konsumen, maka konsumen akan terus menerus menggunakan jasanya sehingga kesuksesan akan diperoleh.

2. Pengertian, Klasifikasi dan Karakteristik Jasa

a. Pengertian Jasa

Pada hakekatnya tujuan pelayanan jasa yaitu memuaskan kebutuhan dan keinginan konsumen. Jasa mempunyai sifat dan ciri tersendiri dibandingkan benda berwujud, maka teknik dalam memasarkan antara produk dan jasa berbeda. Pengertian jasa menurut Kotler (1997:38) yaitu:

"Jasa adalah setiap tindakan yang dapat ditawarkan oleh suatu pihak kepada pihak lain. Pada dasarnya jasa tidak berwujud dan tidak mengakibatkan kepemilikan apapun. Produk jasa mungkin atau tidak mungkin berkaitan dengan produk fisik".

\section{Kerangka Pemikiran}

Sebagai gambaran dalam menyusun skripsi ini diperlukan adanya sebuah kerangka pemikiran yang terperinci agar pemecahan masalah dapat terarah. Secara skematis kerangka pemikiran digambarkan seperti pada gambar 1 berikut ini :

\section{Gambar1. Kerangka Pemikiran Penelitian}

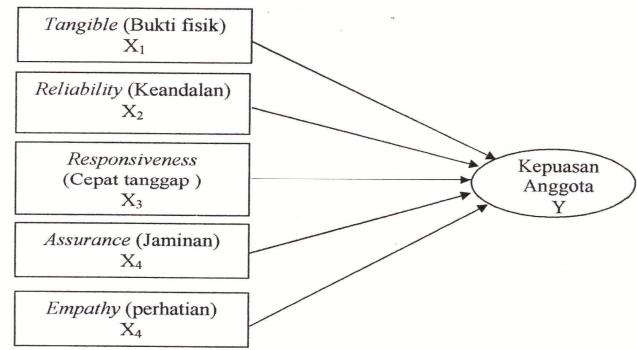

Sumber: (Sri Mulyani 2008, Wijarnako 2008) 


\section{HASIL DAN PEMBAHASAN}

Persamaan koefisien regresi linier berganda yang diperoleh adalah sebagai berikut:

$\mathrm{Y}=6,264+0,283 \mathrm{X}_{1}+0,563 \mathrm{X}_{2}+0,714 \mathrm{X}_{3}-$ $0,567 \mathrm{X}_{4}-0,412 \mathrm{X}_{5}$

Persamaan tersebut dijabarkan sebagai berikut

a. Konstanta $=6,264$ persamaan regresi mempunyai konstanta yang mengidentifikasikan bahwa apabila variabel bukti fisik, reliability, responsivenees, assurance, empathy, dianggap konstan atau nol, maka kepuasan anggota koperasi dosen dan karyawan AUB Pancasila Surakarta positif.

b. $\beta_{1}=0,283$. Variabel bukti fisik berpengaruh positif terhadap kepuasan anggota koperasi dosen dan karyawan AUB Pancasila Surakarta, artinya apabila variabel bukti fisik meningkat maka kepuasan anggota meningkat dengan asumsi variabel reliability, responsivenees, assurance dan empathy konstan (tetap).

c. $\beta_{2}=0,563$. Variabel reliability berpengaruh positif terhadap anggota koperasi dosen dan karyawan AUB Pancasila Surakarta, artinya apabila variabel reliability meningkat maka kepuasan anggota meningkat dengan asumsi variabel bukti fisik, responsivenees, assurance dan empathy konstan konstan (tetap).

d. $\beta_{3}=0,714$. Variabel responsivenees berpengaruh positif terhadap anggota koperasi dosen dan karyawan AUB Pancasila Surakarta, artinya apabila variabel responsivenees meningkat maka kepuasan anggota meningkat dengan asumsi variabel bukti fisik, reliability, assurance, dan empathy konstan (tetap).

e. $\beta_{4}=-0,567$. Variabel assurance berpengaruh negatif terhadap anggota koperasi dosen dan karyawan AUB Pancasila Surakarta, artinya apabila variabel assurance menurun maka kepuasan anggota koperasi menurun dengan asumsi variabel bukti fisik, reliability, responsivenees dan empathy konstan (tetap).

f. $\beta_{5}=-0,412$. Variabel empathy berpengaruh negatif terhadap kepuasan anggota koperasi dosen dan karyawan AUB Pancasila Surakarta, artinya apabila variabel empaty meningkat maka kepuasan anggota koperasi meningkat dengan asumsi variabel bukti fisik, reliability, responsiveness, assurance,empathy konstan (tetap).

Uji t

Kesimpulan Hasil Hasil Uji t

1) Hasil perhitungan variabel bukti fisik diperoleh nilai $\mathrm{t}$ hitung $(2,586)>\mathrm{t}_{\text {tabel }}$ $(0,166)$, dengan taraf signifikan $(0,292<$ $0,05)$ maka Ho ditolak, berarti variabel bukti fisik berpengaruh signifikan terhadap kepuasan anggota koperasi dosen dan karyawan AUB Pancasila Surakarta, sehingga hipotesis kedua terbukti.

2) Hasil perhitungan variabel reliability diperoleh nilai $\mathrm{t}$ hitung $(2,431)>\mathrm{t}_{\text {tabel }}$ $(0,166)$, dengan taraf signifikan $(0,020<0,05)$ maka Ho ditolak, berarti variabel reliability berpengaruh signifikan terhadap kepuasan koperasi dosen dan karyawan AUB Pancasila Surakarta, sehingga hipotesis kedua terbukti.

3) Hasil perhitungan variabel responsivenees diperoleh nilai $\mathrm{t}$ hitung $(2,512)>\mathrm{t}_{\text {tabel }}$ $(0,166)$, dengan taraf signifikan $(0,016<$ $0,05)$ maka Ho ditolak, berarti variabel responsivenees berpengaruh signifikan terhadap kepuasan koperasi dosen dan karyawan AUB Pancasila Surakarta, sehingga hipotesis kedua terbukti.

4) Hasil perhitungan variabel assurance diperoleh nilai $\mathrm{t}_{\text {hitung }}-2,144<\mathrm{t}_{\text {tabel }} 0,166$ dengan taraf signifikan $(-0,038>0,05)$ maka Ho diterima, berarti variabel assurance berpengaruh tidak signifikan terhadap kepuasan koperasi dosen dan karyawan AUB Pancasila Surakarta sehingga hipotesis keempat tidak terbukti.

5) Hasil perhitungan variabel empathy diperoleh nilai $t_{\text {hitung }}-3,004<t_{\text {tabel }} 0,166$ dengan taraf signifikan $(0,005<0,05)$ maka Ho diterima, berarti variabel assurance berpengaruh tidak signifikan terhadap kepuasan koperasi dosen dan karyawan AUB Pancasila Surakarta sehingga hipotesis keempat tidak terbukti.

\section{Uji F}

Kesimpulan Hasil Uji F

Nilai $\mathrm{F}$ hitung $(8,942>$ dari nilai $\mathrm{F}$ tabel $(2,31)$ dengan tingkat signifikansi 0,000 maka Ho ditolak sehingga ada pengaruh yang signifikan bukti fisik, reliability, responsivenees, assurance dan empathy terhadap kepuasan 
anggota koperasi dosen dan karyawan AUB Pancasila Surakarta secara simultan.

\section{Koefisien Determinasi}

Perhitungan program SPSS diperoleh nilai Adjusted $R$ Square 0,469 , memberikan makna bahwa $72,6 \%$ variabel kepuasan anggota dapat dijelaskan oleh variabel bukti fisik, reliability, responsivenees, assurance dan empathy sedangkan sisanya sebesar $27,4 \%$ dijelaskan variabel lain yang tidak dimasukkan dalam model regresi ini misalnya kualitas produk, harga atau biaya dan sebagainya.

\section{Implikasi Manajerial}

1. Untuk mengetahui kepuasan anggota bisa dilakukan meningkatkan responsiveness dengan cara pegawai tanggap terhadap permasalahan yang dihadapi oleh anggota, cepat dan tepat dalam memberikan informasi kepada para anggota cepat dan tepat dalam memenuhi permintaan anggota.

2. Untuk mengetahui kepuasan anggota bisa dilakukan meningkatkan assurance dengan cara pegawai sopan kepada para anggota, profesionalisme dan pengetahuan yang luas tentang produk koperasi dosen dan karyawan AUB Pancasila Surakarta dan anggota merasa aman dalam melakukan perjanjian dengan karyawan.

3. Untuk mengetahui kepuasan anggota bisa dilakukan meningkatkan reliability dengan cara pegawai koperasi dosen dan karyawan AUB Pancasila Surakarta memberikan informasi yang akurat bagi anggota, pelayanan konsultasi dilakukan dengan baik oleh pegawai koperasi dosen dan karyawan AUB Pancasila Surakarta dan 7koperasi dosen dan karyawan AUB Pancasila Surakarta tepat waktu dalam melayani anggota.

4. Untuk mengetahui kepuasan anggota bisa dilakukan meningkatkan tangibles dengan cara penampilan pegawai yang menarik, tampilan gedung dan tata letak yang memberikan kenyamanan bagi anggota dan tampilan gedung dan display produk menarik.

5. Untuk mengetahui kepuasan anggota bisa dilakukan meningkatkan empathy dengan cara kemudahan dalam memperoleh informasi tentang perbankan, kemudahan dalam melakukan komunikasi antara anggota dengan pegawai koperasi dosen dan karyawan AUB Pancasila Surakarta menanggapi setiap keluhan anggota dengan baik.

\section{KESIMPULAN DAN SARAN}

1. Kesimpulan

Berdasarkan Hasil pengolahan data dan analisis yang telah dilakukan, maka dapat disimpulkan sebagai berikut:

a. Hasil perhitungan variabel bukti fisik diperoleh nilai $\mathrm{t}$ hitung $(2,586)>\mathrm{t}_{\text {tabel }}$ $(0,166)$, dengan taraf signifikan $(0,292<$ $0,05)$ maka Ho ditolak, berarti variabel bukti fisik berpengaruh signifikan terhadap kepuasan anggota koperasi dosen dan karyawan AUB Pancasila Surakarta, sehingga hipotesis kedua terbukti.

b. Hasil perhitungan variabel reliability diperoleh nilai $\mathrm{t}$ hitung $(2,431)>\mathrm{t}_{\text {tabel }}$ $(0,166)$, dengan taraf signifikan $(0,020<0,05)$ maka Ho ditolak, berarti variabel reliability berpengaruh signifikan terhadap kepuasan koperasi dosen dan karyawan AUB Pancasila Surakarta, sehingga hipotesis kedua terbukti.

c. Hasil perhitungan variabel responsivenees diperoleh nilai $\mathrm{t}$ hitung $(2,512)>\mathrm{t}_{\text {tabel }}$ $(0,166)$, dengan taraf signifikan $(0,016<$ 0,05) maka Ho ditolak, berarti variabel responsivenees berpengaruh signifikan terhadap kepuasan koperasi dosen dan karyawan AUB Pancasila Surakarta, sehingga hipotesis kedua terbukti.

d. Hasil perhitungan variabel assurance diperoleh nilai $\mathrm{t}_{\text {hitung }}-2,144<\mathrm{t}_{\text {tabel }} 0,166$ dengan taraf signifikan $(-0,038>0,05)$ maka Ho diterima, berarti variabel assurance berpengaruh tidak signifikan terhadap kepuasan koperasi dosen dan karyawan AUB Pancasila Surakarta sehingga hipotesis keempat tidak terbukti.

e. Hasil perhitungan variabel empathy diperoleh nilai $\mathrm{t}_{\text {hitung }}-3,004<\mathrm{t}_{\text {tabel }} 0,166$ dengan taraf signifikan $(0,005<0,05)$ maka Ho diterima, berarti variabel assurance berpengaruh tidak signifikan terhadap kepuasan koperasi dosen dan karyawan AUB Pancasila Surakarta sehingga hipotesis keempat tidak terbukti.

f. Perhitungan program SPSS diperoleh nilai Adjusted $R$ Square 0,469 , memberikan makna bahwa $72,6 \%$ 
variabel kepuasan anggota dapat dijelaskan oleh variabel bukti fisik, reliability, responsivenees, assurance dan empathy sedangkan sisanya sebesar $27,4 \%$ dijelaskan variabel lain yang tidak dimasukkan dalam model regresi ini misalnya kualitas produk, harga atau biaya dan sebagainya.

2. Saran

a. Responsiveness (Ketanggapan)

Dalam meningkatkan kepuasan nasabah maka pengurus koperasi dosen dan karyawan AUB Pancasila Surakarta harus memperhatikan beberapa hal diantaranya meningaktakan pelayanan kepada nasabah, ketanggapan (Responsiveness) terhadap permasalahan yang dihadapi oleh nasabah perlu ditingkatkan, sikap cepat dan tepat dalam memenuhi permintaan, anggota koperasi dosen dan karyawan AUB Pancasila Surakarta sebaiknya perlu meningkatkan sikap selalu siap membantu menyelesaikan berbagai keluhan yang dihadapi nasabah, karena semua hal itu sangat berpengaruh terhadap kepuasan nasabah.

b. Assurance (Jaminan)

Dalam meningkatkan kepuasan nasabah maka pengurus koperasi dosen dan karyawan AUB Pancasila Surakarta harus memperhatikan beberapa hal diantaranya meningkatkan profesionalisme dan pengetahuan yang luas tentang perbankan dari anggota koperasi dosen dan karyawan AUB Pancasila Surakarta, Sikap sopan kepada nasabah sebaiknya perlu ditingkatkan karena hal ini berpengaruh terhadap kepuasan anggota, koperasi dosen dan karyawan AUB Pancasila Surakarta perlu meningkatkan rasa aman bagi nasabah yang ingin melakukan perjanjian dengan, keterampilan dalam memberikan pelayanan.

c. Tangible (Tampilan Fisik)

Pimpinan harusnya meningkatkan tampilan gedung dan tata letak yang memberikan kenyamanan bagi nasabah, display produk sebaiknya perlu ditingkatkan karena hal ini berpengaruh kterhadap kepuasan nasabah, penampilan karyawan yang menarik sebaiknya perlu ditingakatkan karena berpengrauh terhadap kepuasan nasabah, Lingkungan koperasi dosen dan karyawan AUB Pancasila Surakarta yang bersih dan rapi sebaiknya perlu ditingkatkan, kerapian dan kebersihan anggota koperasi dosen dan karyawan AUB Pancasila Surakarta sebaiknya perlu ditingkatkan.

d. Koperasi dosen dan karyawan AUB Pancasila Surakarta dalam meningkatkan kepuasan nasabah diharapkan untuk meningkatkan kualitas pelayanan, sebab pelayanan yang kurang baik akan mengakibatkan nasabah segan melakukan transaksi simpan pinjam di koperasi dosen dan karyawan AUB Pancasila Surakarta karena merasa tidak puas atas pelayanan yang diberikan. Demikian juga dengan pelayanan yang baik nasabah akan selalu melakukan simpan pinjam di koperasi dosen dan karyawan AUB Pancasila Surakarta karena merasa puas atas pelayanan yang diberikan sehingga keuntungan yang diperoleh koperasi dosen dan karyawan AUB Pancasila Surakarta juga akan meningkat.

\section{DAFTAR PUSTAKA}

Arikunto, Suharsimi. 2003. Prosedur Penelitian : Suatu Pendekatan Praktek. Jakarta Rineka Cipta

Basu Swastha Dharmesta dan Handoko, Hani. 2003. Manajemen Pemasaran Analisys Perilaku Konsumen. Yogyakarta: BPFE.

Dewi Widoretno, 2007, Analisis Pongaruh Relationship Marketing terhadap Tingkat Kepuasan Pelanggan A (Studi Kasus Nasabah Bank Jateng cabang Sragen) Surakarta. STIE AUB Surakarta

Ghozali, Imam. 2004. Analisis Multivariate dengan Program SPSS. Semarang Badan Pcnerb t Universitas Diponegoro.

Hadi, Sulistyo Bagus, 2002, Analisis Faktor faktor yang menentukan Kepuasan Pelanggan dan Pengaruhnya terhadap Loyalitas Pelanggan, Tesis Tidak Dipublikasikan, Program Magister Manajemen Universitas Diponegoro, Semarang

Harjati, Lily, 2003, "Tidak Cukup Hanya Kepuasan Pelanggan-Diperlukan Midi

Pelanggan untuk Survival," Jurnal Ekonomi Perusahaan, Vol 10 Nol, Maret Kotler Philip dan AB. Susanto, 2001 Manajemen Pemasaran di Indonesia, Jakarta, Salemba Empat.

Kotler Philip, 2000, Marketing Management ; 
The Millenium Edition, New Jersey, Prentice Hall

Tjiptono, Fandy dan Anastasia Diana, 2003, Total Quality Management, Yogjakarta. Andi Offset

Tjiptono,. Dandy dan Gregorius Candra, 2005. Service, Quality and Satisfacation, Yogjakarta. Andi Offset

Karsono. 2005. Pengaruh Kualitas Pelayanan Terhadap Loyalitas Konsumen dengan Kepuasan Sebagai Variabel Pemediasi, Jurnal Bisnis \& Manajemen, Vol. 5, No. 2, hal. 183-196.

Kotler, Phillip. 2003. Marketing Management. 11"' Edition, New Jersey ;

Prentice Hall. Inc. Upper Saddle 